\title{
Some aspects need to be considered in assessment and treatment of sarcopenia
}

This article was published in the following Dove Press journal:

Clinical Interventions in Aging

\author{
Tugba Erdogan \\ Gulistan Bahat \\ Department of Internal Medicine, \\ Division of Geriatrics, Istanbul \\ University, Istanbul Medical School, \\ Istanbul, Turkey
}

\section{Dear editor}

We have read the review article by Ilaria Liguori et $\mathrm{al}^{1}$ with great interest. In this article, authors aimed to review sarcopenia in terms of assessment of its burden and strategies to improve outcomes. We have some comments that would contribute on this extensive review.

Authors reported that the diagnosis of sarcopenia requires the presence of both low muscle mass and low muscle function. Authors defined low muscle function as gait speed lower than $0.8 \mathrm{~m} / \mathrm{s}$ and/or a grip strength lower than $26-30 \mathrm{~kg}$ for men and 16-20 kg for women. However, it should be noted that European Working Group on Sarcopenia in Older People (EWGSOP) recommends use of normative data of the study population for muscle mass and muscle strength cutoff points. After EWGSOP publication, population-specific cutoff values, including the Turkish and Korean population, have been published and better to be included in a paper aimed to review sarcopenia in this context. ${ }^{2}$

The authors noted that, starting from skeletal muscle mass calculated using the Janssen BIA equation, skeletal muscle mass index $(\mathrm{SMI})=$ (skeletal muscle mass/body mass) $\times 100$; low muscle mass is defined by an SMI $\leq 8.87 \mathrm{~kg} / \mathrm{m}^{2}$ for men and $\leq 6.42 \mathrm{~kg} / \mathrm{m}^{2}$ for women. However, these cutoff values are SMI cutoff values when the skeletal muscle mass is adjusted by height and not body mass. The cutoff values of skeletal muscle mass adjusted by body mass determined by this methodology are $29.0 \%$ for men and $20.5 \%$ for women, and this should be corrected. ${ }^{3}$

The authors reported that testosterone is the most effective and safest drug among the drugs investigated for the treatment of sarcopenia, because its adverse effects are dose dependent and associated with very high doses of 300-600 mg/week. However, the dose of 300-600 mg/week testosterone mentioned in this study is well above the recommended dose for standard hypogonadism treatment (at least 2-4 times). In 2017 study derived from the major Testosterone Treatment Trials (TTT), it is stated that testosterone-related side effects may occur even at the recommended low doses for hypogonadism, that is, increase in coronary artery noncalcified plaque volume. ${ }^{4}$ Additionally, in another study derived from TTT, it is shown that testosterone does not increase physical function. Because of these reasons, it is difficult to say that testosterone is the safest and most effective drug.

Regarding future therapeutic approaches, authors denoted some agents, that is, selective androgen receptor modulator enobosarm, ghrelin receptor agonist anamorelin, monoclonal antibodies, and stem-cell approaches. However, there are many more 
agents that should be stated in this regard, that is, espindolol, ruxolitinib, peroxisome proliferator-activated receptor delta agonists, AICA (5-aminoimidazol-4-karboksamid-1-beta4-ribafuranosid), biguanids, tripartite motif-containing 32 inhibitors, growth differentiation factor (GDF11), ciliary neurotrophic factor agonist, myokines activators and inhibitors, CisD protein replacement, sirtuins/reservatol/polyphenols, nitric oxid (isorbide dinitrite), microRNAs (miR-1, miR-29, miR208, and miR486) modulators, RNA antisense, PGCI $\alpha$ agonist, and serum and glucocorticoid inducible kinase 1 (SGK1). It would be better to be included in a paper aimed to review sarcopenia in this context. ${ }^{5}$

\section{Disclosure}

The authors declare no conflicts of interest in this communication.

\section{References}

1. Liguori I, Russo G, Aran L, et al. Sarcopenia: assessment of disease burden and strategies to improve outcomes. Clin Interv Aging. 2018;13: 913-927.

2. Bahat G, Tufan A, Tufan F, et al. Cut-off points to identify sarcopenia according to European Working Group on Sarcopenia in Older People (EWGSOP) definition. Clin Nutr. 2016;35(6):1557-1563.

3. Janssen I, Heymsfield SB, Baumgartner RN, Ross R. Estimation of skeletal muscle mass by bioelectrical impedance analysis. $J$ Appl Physiol (1985). 2000;89(2):465-471.

4. Budoff MJ, Ellenberg SS, Lewis CE, et al. Testosterone treatment and coronary artery plaque volume in older men with low testosterone. JAMA. 2017;317(7):708-716.

5. Morley JE. Pharmacologic options for the treatment of sarcopenia. Calcif Tissue Int. 2016;98(4):319-333.

Dove Medical Press encourages responsible, free and frank academic debate. The content of the Clinical Interventions in Aging 'letters to the editor' section does not necessarily represent the views of Dove Medical Press, its officers, agents, employees, related entities or the Clinical Interventions in Aging editors. While all reasonable steps have been taken to confirm the content of each letter, Dove Medical Press accepts no liability in respect of the content of any letter, nor is it responsible for the content and accuracy of any letter to the editor.

\section{Publish your work in this journal}

Clinical Interventions in Aging is an international, peer-reviewed journal focusing on evidence-based reports on the value or lack thereof of treatments intended to prevent or delay the onset of maladaptive correlates of aging in human beings. This journal is indexed on PubMed Central, MedLine,
CAS, Scopus and the Elsevier Bibliographic databases. The manuscript management system is completely online and includes a very quick and fair peer-review system, which is all easy to use. Visit http://www.dovepress. com/testimonials.php to read real quotes from published authors. 